\title{
ФОРМИРОВАНИЕ ЭКОСИСТЕМЫ ЦИФРОВОЙ ЭКОНОМИКИ: ТЕХНОЛОГИЧЕСКИЙ И ИНСТИТУЦИОНАЛЬНЫЙ АСПЕКТЫ, МЕЖДУНАРОДНЫЙ ОПЫТ И ИМПЛЕМЕНТАЦИЯ В РЕСПУБЛИКЕ БЕЛАРУСЬ
}

\author{
И.В. Новикова, В.Б. Криштаносов *
}

\begin{abstract}
Исследуются проблемы формирования экосистемы для становления и развития цифровой экономики в рамках институционального контекста развития. Цифровизация, являясь по своему характеру эндогенным, технологическим фактором экономического развития, становится важным его институтом в современных условиях. Институционализация цифровой экономики - методологически сложный процесс и требует учета временного фактора и последовательности действий государственного и частного секторов с целью придания непротиворечивого характера и динамики экономическим процессам. Данный подход раскрыт на основе складывающейся практики формирования институтов цифровой экономики в Республике Беларусь и анализа ключевых критериев, необходимых для ее становления и развития.
\end{abstract}

Ключевые слова: цифровая экономика, институциональная матрица экосистемы цифровой экономики, три уровня развития экосистемы цифровой экономики.

JEL-классификация: O33, O38, F52.

DOI: $10.46782 / 1818-4510-2021-4-124-137$

Материал поступил 6.12.2021 2.

Последние десятилетия XX и начало XXI в. ознаменовали собой новый этап в развитии человеческой цивилизации, в основном в ее экономической подсистеме переход к цифровой экономике и изменение парадигмы экономического развития (Новикова, 2020). Еще в конце XX в., говоря о смене парадигмы развития, К. Фримен отмечал: «Современное изменение парадигмы можно рассматривать как сдвиг от технологий, основанных главным образом на вложении дешевой энергии, к технологиям, основанным преимущественно на дешевых вложениях информации, почерпнутых из успехов в микроэлектрони- ке и телекоммуникационных технологиях» (Freeman, Soete, 1997).

\section{Методология анализа әкономического развития в технологическом и институциональном контекстах}

В современном обществе, характеризующемся стремительными изменениями в технологических, организационных и управленческих инновациях, связанных с цифровизацией, меняются подходы к экономическому развитию и сам его характер. Если К. Маркс рассматривал производственные отношения как своего рода «упаковку» производительных сил, и с этой точ-

* Новикова Ирина Васильевна (хеnia2012@belstu.by), доктор экономических наук, профессор, Белорусский государственный технологический университет (г. Минск, Беларусь). https://orcid.org/0000-0002-9710-8872;

Криштаносов Виталий Брониславович (krishtanosov@mail.ru), кандидат экономических наук, Белорусский государственный технологический университет (г. Минск, Беларусь). https://orcid.org/0000-0002-1146-368X 
ки зрения у него, одного из первых, производительные силы были эндогенным фактором развития, то современные экономические школы уже не подвергают сомнению тот факт, что технологии являются эндогенными факторами экономической системы и ее развития.

Одной из первых версий теории эндогенного роста была теория, разработанная M. Франкелем (Frankel, 1962), в которой не проводилось явного различия между накоплением капитала и технологическим прогрессом. По сути, он объединил физический и человеческий капитал, накопление которого изучается неоклассической теорией, с интеллектуальным капиталом, который накапливается при появлении инноваций. Современные модели эндогенного роста, связанного с такими эндогенными факторами, как человеческий капитал и инновации, более детально рассмотрены в работе (Быков, Шаблинская, 2020. С. 5).

В частности, американские ученые Д. Аджемоглу, С. Джонсон и Дж.А. Робинсон утверждают, что институциональные изменения являются эндогенными. Они создают базу для последующих институциональных изменений, основанную на распределении ресурсов в обществе и уже существующих политических институтах. Эти два фактора определяют политическую власть де-юре и де-факто соответственно, что, в свою очередь, определяет экономические институты данного периода и политические институты следующего периода. Наконец, текущие экономические институты определяют распределение ресурсов в следующий период, и цикл повторяется (Acemoglu, Johnson, Robinson, 2005). Таким образом, и технологические изменения, и институты являются внутренними факторами развития. Ведь что такое институты? Институты - это «стабильные, ценные, повторяющиеся модели поведения», - отмечал С. Хантингтон (2004). А повторяющиеся модели поведения, в том числе в экономике, могут «повторяться» только при наличии политических институтов, адаптированных к этим изменениям «предыдущего цикла».

Что касается политико-экономических институтов, то классическим определением здесь выступает определение Д. Норта (1997): «Институты - это «правила игры» в обществе, или выражаясь более формально, созданные человеком ограничительные рамки, которые организуют взаимоотношения людей ... Наряду с применяемой технологией они определяют трансакционные и трансформационные (производственные) издержки, которые в совокупности составляют общие издержки производства ... Институты не обязательно - и даже далеко не всегда - создаются для того, чтобы быть социально эффективными; институты или, по крайней мере, формальные правила, создаются скорее для того, чтобы служить интересам тех, кто занимает позиции, позволяющие влиять на формирование новых правил». В самом общем смысле институты являются «строительными блоками социального порядка: они представляют собой социально санкционированные, то есть коллективно навязываемые ожидания в отношении поведения определенных категорий субъектов или выполнения определенных действий. Обычно они включают в себя взаимосвязанные права и обязанности субъектов» (Streeck, Thelen, 2005).

Следует отметить, что формирование новых институтов и трансформация старых - это не одномоментный процесс. Д. Норт описывает институциональные изменения как чрезвычайно постепенный процесс, который работает как через формальные, так и неформальные институты. В свою очередь, В.М. Полтерович (2017. С. 9), занимающийся проблемами институциональных реформ на постсоветском пространстве, отмечает следующее по поводу формирования новых институтов: «Чтобы добиться успеха, надо рассматривать реформы не как одномоментный акт принятия соответствующих законов, а как последовательность преобразований, построение институциональной траектории, ведущей к намеченной цели». Таким образом, определенная систематизированная совокупность институтов и элементов какой-либо системы формирует экосистему для развития. При этом и совокупность институтов, и технологические изменения, являясь внутренними, эндогенными факторами развития, вопервых, только в совокупности запускают экономическое развитие. А во-вторых, каждый из этих компонентов развития по от- 
дельности не может обеспечить динамику самого развития. При этом отметим, что институты, возникающие без технологических изменений, не могут обеспечить развития, а технологические изменения не смогут обеспечить динамику развития без новых организационных форм, систем управления и институтов, их обеспечивающих.

Почему речь следует вести не о собственно институциональной среде, а об экосистеме? Данный термин, широко используемый в исследованиях по инновациям (Новикова, 2020. С. 7), был заимствован из методологии экологических исследований. Впервые был введен в научный оборот экологом А. Тенсли (Ayres, 2012). Он подчеркивал, что для экосистем характерен разного рода обмен веществ не только между организмами, но и между органическим и неорганическим веществом, и этот комплекс представляет собой систему, обусловленную единой историей и со способностью к согласованному развитию. С этой точки зрения, необходимо определиться с траекторией институционализации цифровой экономики и выделением последовательностей в ее становлении и развитии.

\section{Институционализация әкосистемы цифровой экономики}

Цифровизация - общий термин для обозначения тенденции и воздействия растущего использования цифровых технологий ${ }^{1}$. Цифровизация создает новые цифровые возможности, которые оказывают преобразующее влияние на организацию экономической деятельности, поддерживая радикальные инновации в бизнес-моделях. Согласно определению Тильсона, Литтинена, Соренсена, цифровизация - это социотехнический процесс применения методов оцифровки в более широком социальном и институциональном контексте, который делает цифровые технологии инфраструктурными (Tilson, Lyytinen, Sorensen, 2010). По мнению Миллера (2020), цифровизация способствовала созданию совершенно новых цифровых рынков, управляемых платформенными предприятиями на основе открытой бизнес-модели, позволяющей свя-

Термин «цифровой» происходит от латинского сло- зываться и взаимодействовать друг другом и внешним потребителям, и производителям. Организация экономического сотрудничества и развития (ОЭСР) отмечает, что стремительный рост вычислительной мощности оборудования, емкости для хранения данных и скорости связи создали условия для появления обширной и разнообразной экосистемы технологий ${ }^{2}$.

Комплексное изучение влияния ИКТ на экономические системы, их адаптацию и трансформацию под влиянием цифровых инноваций привело к созданию концепции «цифровой экономики», которую в 1995 г. сформулировал Тэпскотт. Оверби и Аудестад предложили рассмотрение цифровой экономики как экономики, основанной на цифровых товарах и услугах, чей бизнесландшафт сформирован такими технологиями, как: социальные сети, мобильные приложения, облачные вычисления, запоминающие устройства, криптовалюты и сервисы обмена (Overby, Audestad, 2018).

Согласно отчету Конференции ООН по торговле и развитию (ЮНКТАД), цифровая экономика рассматривается в трех измерениях: 1) базовый - представлен сектором ИКТ; 2) в узком смысле - представлен цифровой экономикой и экономикой цифровых платформ; 3) в широком смысле - представлен «оцифрованной» экономикой ${ }^{3}$.

В настоящее время формируется принципиально новая экономическая система и новая совокупность производственных, социальных и экономических отношений, новизна которых заключается в их алгоритмизации и платформизации, синергии метатехнологий и цифровых концепций.

Анализ подходов к трактовке понятия «экосистема» в отношении цифровой экономики позволяет рассматривать ее не только как совокупность правил и норм, регулирующих взаимодействие населения, хозяйствующих субъектов, органов государственного управления в отношении становления и развития цифровой эконо-

${ }^{2}$ Going Digital: Shaping Policies, Improving Lives. 2019. OECD. URL: https://www.oecd.org/publications/going-digitalshaping-policies-improving-lives-9789264312012-en.htm

3 Digital Economy Report 2019. Value Creation and Capture: Implications for Developing Countries. UNCTAD. URL: https://unctad.org/webflyer/digital-economy-report-2019 
мики, но и как определенную алгоритмизацию.

Схема показывает (рис. 1), что чем больше угол наклона нижней кривой, тем быстрее идет становление институтов новой системы. Чем более пологий характер у верхней кривой, тем лучше работает экосистема для новых институтов. Верхняя крива «толкает» тренд развития системы вниз. А нижняя, напротив, вверх. Данная система демонстрирует роль времени в создании институтов и необходимости матрицы формирования новых институтов и отмирания старых.

В научной литературе, как правило, институты классифицируют по таким признакам, как: правовые, экономические, организационно-управленческие и финансовокредитные. При этом Ходжсон определяет институты как «долгосрочные институты сложившихся и укорененных правил, которые придают структуру социальным взаимодействиям» (Ходжсон, 2003). Сирл отмечает, что институты представляют собой особый тип социальной структуры, включающий кодифицируемые правила интерпретации и поведения (Searle, 1995).

Следует отметить, что институты играют важную роль в качестве информационных ориентиров, необходимых для деятельности в сложной и лишь отчасти известной и понятной экономической среде. Они предполагают наличие легитимности принимаемых решений в социальной сре-

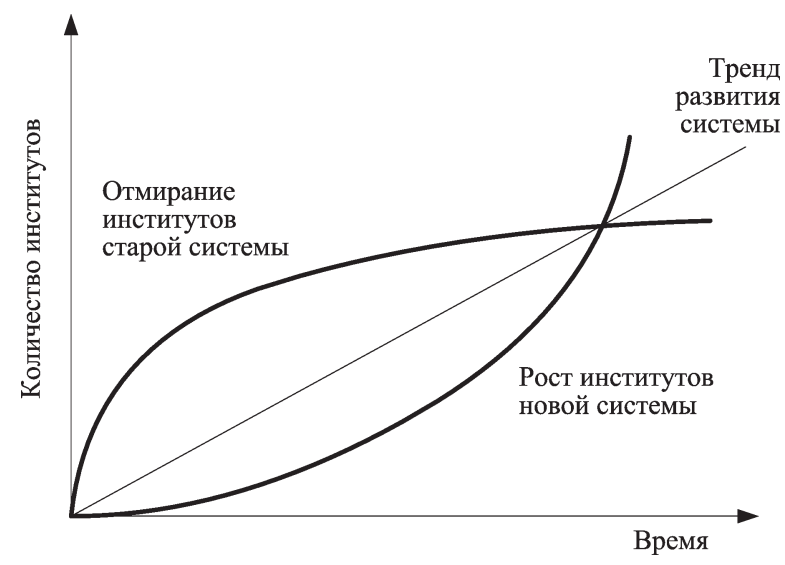

Рис. 1. Взаимодействие институтов старой и новой систем, определяющее развитие системы с учетом временных лагов

Источник. Авторская разработка. де и представляют собой не только организационные структуры, но и нормативные модели поведения.

Экономическими институтами в современной экономике являются рынки и компании. Рынки представляют собой организованный и институциональный обмен. Главную роль играют институты, которые способствуют упорядочиванию цен, установлению консенсуса в связи с ними и, в более агрегированном виде, распространению информации о продуктах, ценах, объемах, а также о потенциальных покупателях и продавцах.

Как отметил Уильямсон, «главной целью и результатом функционирования... институтов [типа фирмы] является минимизация трансакционных издержек» (Williamson, 1985). Трансакционные издержки, согласно Дальману, включают: 1) поисковые и информационные издержки; 2) издержки, сопряженные с ведением переговоров и принятием решения; 3) издержки надзора и принуждения к соблюдению контракта (Dahlman, 1979). Представляется, что в цифровой экономике все три компонента находят следующее отражение: 1) поисковые и информационные издержки по затратам значительно сокращаются, при этом их глубина, системность и проработанность становятся определяющими для успешной бизнес-деятельности компаний; 2) цифровизация систем управления, аналитика больших данных и искусственный интеллект (ИИ) уменьшают вероятность ошибки и позволяют осуществлять прогнозирование в деятельности компании и развитии рынков с большей точностью, тем самым сокращая вероятность человеческого фактора и ошибки, позволяя преодолеть отдельные неопределенности рынка; 3) издержки надзора напрямую связаны с концепцией RegTech. Соблюдение контракта с использованием технологий смарт-контрактов делает процесс автоматизированным, сокращает издержки по контролю за данным процессом.

Как отмечает Ходжсон, добиться экономии информационных издержек возможно за счет агрегирования агентов, участвующих в торговле под «институциональным зонтиком». Фактически речь может идти о 
концепции платформизации и экосистемы в рамках цифровой экономики (Ходжсон, 2003).

Важными институтами функционирования институциональной среды являются правовые нормы. Правовые контрактные институты дополняют институты рынка. Например, контракт базируется на сочетании законов, издаваемых правительством, обычаев и традиций, в основе которых лежит сочетание формального законодательства и легитимации. В цифровой экономике, по нашему мнению, возможным заместителем традиционного контрактного права является технологическая концепция смарт-контрактов, предполагающая автоматическое исполнение цифровых сделок без участия посредника.

Государственное регулирование всегда носит институциональный характер. Необходимость трансформации инструментов государственного регулирования обоснована «законом необходимого разнообразия» Эшби, который гласит, что разнообразие управляющей системы должно быть не меньшим, чем разнообразие управляемой системы ${ }^{4}$. Открытая система для минимизации вероятности своего разрушения должна быть достаточно разнообразной. В этой связи цифровизация экономики, на наш взгляд, меняет традиционные отрасли производства. Следовательно, государственное управление в части методов и инструментов должно соответствующим образом трансформироваться. Как отмечает Ходжсон (2003), динамичная новаторская система требует структурированного сочетания разнообразия и неэластичности, статического равновесия и изменений, централизованного руководства и децентрализованной автономии. Вопрос заключается в том, как и по какому критерию делать структуризацию, в данном случае - в цифровой экономике.

Источником многих важных технологических нововведений являются институты, в значительной степени пользующиеся финансовой поддержкой государства (например, университеты в развитых странах). В целом, по мнению институционалистов, необходимо как минимум наличие таких централизованных институтов, как та или

${ }^{4}$ Эшби У.Р. 1959. Введение в кибернетику. Москва: Иностранная литература. иная форма индикативного планирования в сочетании с интервенционистской промышленной политикой, направленной на координацию экономической деятельности и установление приоритетов.

В контексте цифровизации важнейшими элементами развивающей роли государства в становлении институциональной среды являются создание инфраструктуры (материальной и нематериальной), формирующей новые возможности роста экономики, а также развитие НИОКР в рамках промышленной политики. Кроме того, предпосылкой будущей занятости населения является успешная образовательная политика, которая оказывает глубокое влияние как на формирование корпуса квалифицированной рабочей силы, так и на способность населения усваивать новые знания и приобретать новые цифровые навыки (Schuelke-Leech, 2017).

Государство создает экономические и политические условия, которые позволяют хозяйствующим субъектам брать на себя риски, связанные с развитием продуктов и услуг, и в то же время разумно ожидать финансовой отдачи от принятия рисков. Реализация различных государственных мониторинговых функций осуществляется посредством институтов органов власти. Распределительная роль государства включает такие подходы, как: «формирующие предложение» (подход «технологического толчка» - проведение собственных исследований и разработок, стимулирующих распространение технологий) и «формирующие спрос» (государство формирует спрос через закупку определенных технологических решений и инноваций) (Peters, Schneider, Griesshaber, Hoffmann, 2012).

В экономической литературе выделяют три отличительных формы управления национальными цифровыми экосистемами и институциональными структурами (Giannopoulos, Munro, 2019).

1. Система, непосредственно управляемая государством, для которой характерны централизация управления и государственное финансирование. Государственночастное партнерство также является одной из форм финансирования крупных проектов, что позволяет разделить риски, свя- 
занные с разработкой и внедрением цифровых инноваций ${ }^{5}$. Государство сотрудничает с существующими частными фондами, давая возможность инвестировать государственные средства в соответствии с рыночными механизмами.

2. Рыночная система, предполагающая наличие развитого рынка и инновационных экосистем, участники которых осуществляют взаимодействие в условиях развитых и стабильно функционирующих финансовых сетей и систем. Государственное вмешательство ограничивается установлением правил в отношении инвестиций, интеллектуальной собственности, разработки и обеспечения соблюдения правил, регулирующих продажу и эксплуатацию инноваций, а также деятельности по сертификации и оценке технологий.

3. Смешанная, или гибридная система, сочетающая в себе структуры и режимы, которые допускают как рыночные, так и централизованные формы деятельности в области цифровизации.

Следует выделить ряд принципов формирования цифровой институциональной среды. Так, Всемирный экономический форум $^{6}$ для становления цифровой экономики, в том числе цифровых инноваций, предлагает подход, называемый «гибким регулированием» (Agile Regulation), суть которого - в фокусировании на конечном результате, стимулировании самоорганизации вместо навязывания правил ${ }^{7}$. При этом

5 Типичным примером государственной системы является система Китайской Народной Республики. Центральное правительство устанавливает правила, цели, средства и процедуры, а также осуществляет финансирование большинства видов экономической деятельности, включая инновации. Уникальная особенность системы КНР - параллельное существование сильного и динамично развивающегося частного сектора, который функционирует в рыночных условиях под контролем и целеуказанием со стороны правительства. Китай использует государственные средства для создания механизма поддержки стартовой экосистемы, «мультиплицируя» эффект через мобилизацию частных инвестиций и стимулирование коммерциализации приоритетных цифровых технологий. Финансирование осуществляется за счет средств Руководящего фонда технологических инноваций (децентрализованная система управления фондами) (Ding, 2018).

${ }^{6}$ URL https://www.weforum.org/pages/agile-regulationfor-the-fourth-industrial-revolution-a-toolkit-for-regulators

7 Так, Министерство земли, инфраструктуры, транспорта и туризма Японии (MLIT) внедряет данный подход к регулированию, который включает: использование системы исключений, позволяющих проводить испытания автономных транспортных средств, не соответствующих обыч- важным принципом является использование технологически нейтрального подхода в отношении становления институциональной среды цифровых технологий8.

В международной практике используется также подход, основанный на концепции «упреждающего регулирования», который предполагает выявление изменений в окружающей экосреде за определенный период и рассмотрение последствий этих изменений в рамках текущих и будущих стратегий регулирования. Анализ показывает распространение данного подхода посредством создания специализированных подразделений, консультирующих регулирующие органы по вопросам воздействия технологических инноваций и связанной с этим необходимости реформ.

Кроме того, в рамках современных подходов важным элементом регулирования является формирование гибкой национальной нормативной среды для инновационных экспериментов, как правило - отдельного кластера, на который не распространяются отдельные действующие законодательные, организационные, административные, технические нормы и ограничения (регуляторный подход «песочницы»).

\section{Институщиональная матрица әкосистемъ цифровой экономики: практика и международный опыт}

Как показывает практика, формирование государством институциональной среды для становления цифровой экономики включает в себя такие элементы, как:

1) разработка и установление норм и стандартов управления и планирования исследовательским процессом;

2) разработка и установление правил, регулирующих создание цифровых инноваций и функционирование инновационной экосистемы;

ным нормативным требованиям; совместную разработку добровольных технических требований в промышленности (для испытаний автономных транспортных средств); адаптацию технических требований на основе данных испытаний с упором на международную гармонизацию (в рамках Всемирного форума ЕЭК ООН по гармонизации правил в области транспортных средств - WP29).

${ }^{8}$ Растущее число стран, в том числе Дания, Япония и Соединенное Королевство, открыто поощряют принятие данного подхода. 
3) финансирование исследований и цифровых инноваций;

4) разработка и внедрение процедур оценки экономического потенциала внедрения технологий и ее результативности на всех уровнях и этапах;

5) предоставление сертификатов качества;

6) содействие взаимодействию государственного и частного секторов на всех уровнях;

7) поддержка образования и обучения.

При этом в различных государствах с учетом уровня технологического развития, структуры экономики, уровня государственного регулирования и финансовых возможностей реализуются национальные программы и стратегии стимулирования развития цифровой экономики. Элементами таких программ и стратегий, как правило, выступают институциональные блоки: механизмов внедрения и регулирования отдельных цифровых инноваций и концепций; регулирования финансового рынка; защиты киберпространства (рис. 2).

Экстраполяция основных составляющих стратегий и институциональных блоков формирования современной экосистемы цифровой экономики на примере Европейского союза как региона с наиболее развитой институциональной средой позволяет сформировать институциональную матрицу современной экосистемы цифровой экономики (табл. 1).

Как показывают данные таблицы, для базового уровня становления цифровой

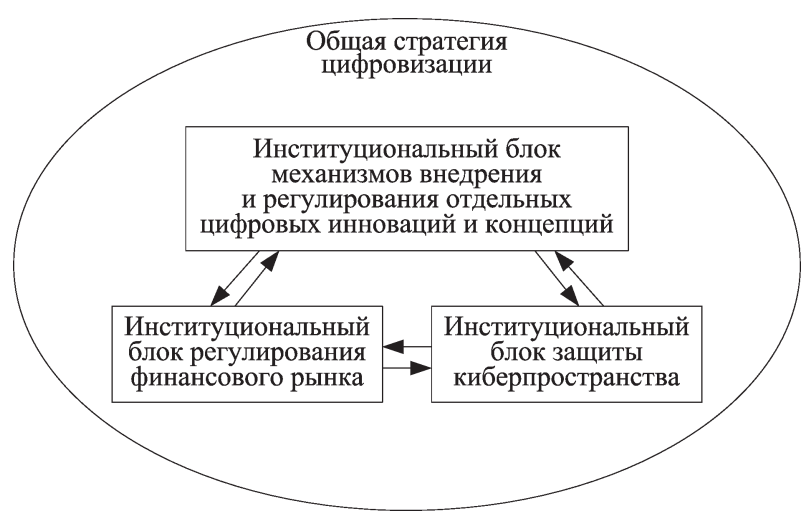

Рис. 2. Элементы институциональной экосистемы цифровой экономики

Источник. Авторская разработка. экосистемы характерны общее стратегическое направление (программа) цифровизации, формируемые институты отдельных цифровых инноваций и концепций, фокусное внимание на противодействие рискам и угрозам, связанным с цифровыми технологиями. Финансовый институциональный блок на данном этапе представлен нишевыми технологиями и не входит в сферу государственного регулирования цифровизации.

Для первого уровня формирования институциональной экосистемы характерно широкое видение направлений развития цифровизации, что выражается в стимулировании развертывания цифровых решений для различных секторов экономики, создание соответствующей инфраструктуры. Институциональный блок цифровых технологий в приоритетах регуляторов уступает место институциональному финансовому блоку, с учетом высокой динамики развития рынка криптовалют и в целом FinTech. Блок цифровой безопасности получил новые организационные институты, призванные предотвратить риски, связанные с киберпреступлениями и усилить международное сотрудничество с учетом их транснационального характера.

Второй уровень развития цифровой экосистемы характеризуется конвергенцией, синергией различных цифровых концепций, их взаимным влиянием, которое накладывает дополнительные требования к комплексному развитию цифровых решений как на технологическом, экономическом, так и социальном уровнях. Институциональная цифровая экосистема становится комплексной, влияющей как на уровне различных рынков, так и отдельных компаний, отраслей и государств. В данном контексте цифровой технологический блок институтов с учетом формирования ключевых концептов цифровизации фокусируется на таких секторах и инновациях, как промышленность, телекоммуникации, цифровые платформы, облачные вычисления. В финансовом институциональном блоке принятие трех ключевых нормативных актов в области обеспечения платежных услуг (MIF, PSD2, GDPR) создали основу для формирования Единой европейской платеж- 
Институциональная матрица экосистемы цифровой экономики на уровне стратегических программ (на примере ЕC)

\begin{tabular}{|c|c|c|c|c|}
\hline Период & $\begin{array}{l}\text { Институ- } \\
\text { циональ- } \\
\text { ный блок }\end{array}$ & Документ (организация), год принятия (создания) & $\begin{array}{l}\text { Институт } \\
\text { регулиро- } \\
\text { вания }\end{array}$ & $\begin{array}{c}\text { Основной объект регулирования в сфере } \\
\text { цифровизации }\end{array}$ \\
\hline \multirow{8}{*}{ 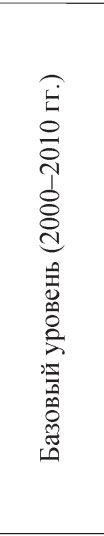 } & СЦ & «Europe $2020 », 2010$ & EK & $\begin{array}{c}\text { Цифровая инфраструктура; единый } \\
\text { цифровой рынок }\end{array}$ \\
\hline & ИБЦИ & Директива об электронной торговле, 2000 & EK & E-Commerce; электронные договоры \\
\hline & ИБФР & - & - & - \\
\hline & \multirow{5}{*}{ ИБЗК } & Конвенция о киберпреступности (Будапештская), 2001 & $\mathrm{CE}$ & Противодействие киберпреступлениям \\
\hline & & $\begin{array}{c}\text { Европейская программа защиты критической } \\
\text { инфраструктуры (ЕРСІР), } 2004\end{array}$ & EK & Защита критической инфраструктуры \\
\hline & & $\begin{array}{c}\text { Европейская сеть предупреждений о критической } \\
\text { инфраструктуре (CIWIN), } 2004\end{array}$ & EK & Защита критической инфраструктуры \\
\hline & & $\begin{array}{c}\text { Рамочное решение Совета о нападениях на } \\
\text { информационные системы (2005/222 / JНА), } 2005\end{array}$ & CE & $\begin{array}{l}\text { Международное сотрудничество } \\
\text { в области уголовного правосудия } \\
\text { в отношении киберпреступлений }\end{array}$ \\
\hline & & $\begin{array}{c}\text { Директива по ЕРСІР по идентификации и обозначению } \\
\text { европейской критической инфраструктуры и оценке } \\
\text { необходимости улучшения ее защиты (2008/114/ЕС), } \\
2008\end{array}$ & $\mathrm{CE}$ & Защита критической инфраструктуры \\
\hline \multirow{8}{*}{ 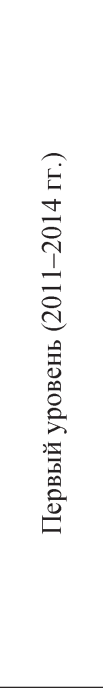 } & СЦ & «Horizon 2020», 2011 & $\begin{array}{l}\text { ЕК, ЕIC, } \\
\text { ЕIT, } \\
\text { Евратом }\end{array}$ & $\begin{array}{l}\text { Исследования и разработки цифровых } \\
\text { технологий, цифровой инфраструктуры; } \\
\text { цифровые промышленные технологии; } \\
\text { энергетика; автономный транспорт }\end{array}$ \\
\hline & ИБЦИ & - & - & - \\
\hline & \multirow{3}{*}{ ИБФР } & Регламент инфраструктуры рынка (EMIR), 2012 & $\begin{array}{c}\text { EП, CE, } \\
\text { EK, ESMA }\end{array}$ & FinTech \\
\hline & & $\begin{array}{c}\text { Директива о рынках финансовых инструментов } \\
\text { (MiFIDII), } 2014\end{array}$ & $\begin{array}{c}\text { EП, CE, } \\
\text { EK, ESMA }\end{array}$ & FinTech \\
\hline & & $\begin{array}{c}\text { Регламент о рынках в финансовых инструментах } \\
\text { (MiFIR), } 2014\end{array}$ & $\begin{array}{c}\text { EП, CE, } \\
\text { EK, ESMA }\end{array}$ & FinTech \\
\hline & \multirow{3}{*}{ ИБЗК } & $\begin{array}{c}\text { Стратегия кибербезопасности ЕС. } \\
\text { Коммюнике ЕС об устойчивости, сдерживании } \\
\text { и защите, } 2013\end{array}$ & EK & $\begin{array}{c}\text { Защита цифровой безопасности граждан, } \\
\text { продуктов и услуг }\end{array}$ \\
\hline & & $\begin{array}{l}\text { Европейский центр киберпреступности при Европоле } \\
\text { (EC3), } 2013\end{array}$ & EK & $\begin{array}{l}\text { Международное сотрудничество } \\
\text { в области уголовного правосудия } \\
\text { в отношении киберпреступлений }\end{array}$ \\
\hline & & $\begin{array}{l}\text { Совместная целевая группа по борьбе } \\
\text { с киберпреступностью (J-САТ), } 2014\end{array}$ & EK & Противодействие киберпреступлениям \\
\hline \multirow{10}{*}{ 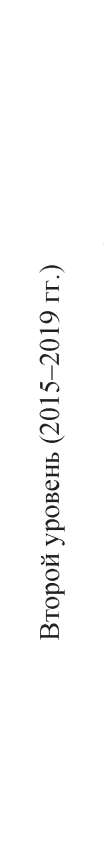 } & СЦ & «Единый цифровой рынок», 2015 & EK & $\begin{array}{c}\text { E-Commerce, НДС, авторские права, } \\
\text { телекоммуникации, онлайн-платформы, } \\
\text { кибербезопасность и защита } \\
\text { персональных данных; экономика } \\
\text { данных; стандарты; цифровые навыки }\end{array}$ \\
\hline & \multirow{4}{*}{ ИБЦИ } & $\begin{array}{c}\text { Инициатива «Гигабитное общество», } 2016 \\
\text { Европейский кодекс электронных коммуникаций }\end{array}$ & EK, BEREC & Телекоммуникации \\
\hline & & $\begin{array}{c}\text { Инициатива по цифровизации европейской } \\
\text { промышленности (DEI), } 2016\end{array}$ & EK & Промышленность \\
\hline & & $\begin{array}{c}\text { Коммюнике Европейской комиссии о платформах } \\
\text { (СОМ (2016) 288/2), } 2016\end{array}$ & EK & Платформизация \\
\hline & & $\begin{array}{l}\text { Стратегия внедрения облачных технологий (ECDS), } \\
2019\end{array}$ & EK & Облачные технологии \\
\hline & \multirow{5}{*}{ ИБФР } & $\begin{array}{c}\text { Руководство по комиссиям за обмен по платежным } \\
\text { картам (MIF), } 2015 \\
\end{array}$ & $\begin{array}{l}\text { EП, CE, } \\
\text { EBA }\end{array}$ & Трансграничные платежи \\
\hline & & $\begin{array}{c}\text { Регулирование операций с финансированием ценных } \\
\text { бумаг (SFTR), } 2015\end{array}$ & $\begin{array}{l}\text { EП, CE, } \\
\text { EK, ESMA }\end{array}$ & Рынок ценных бумаг \\
\hline & & Директива о злоупотреблении рынком (MAD), 2015 & $\begin{array}{c}\text { EП, CE, } \\
\text { EK, ESMA }\end{array}$ & Рынок ценных бумаг \\
\hline & & $\begin{array}{c}\text { Вторая Директива ЕС о платежных услугах (PSD2), } \\
2018\end{array}$ & $\begin{array}{l}\mathrm{E}, \mathrm{CE}, \\
\mathrm{EK}, \mathrm{EBA}\end{array}$ & FinTech \\
\hline & & $\begin{array}{c}\text { Рекомендации по первичным предложениям монет } \\
\text { («ICO») и криптоактивам (RTS, ITS), } 2019\end{array}$ & ESMA & Криптоактивы \\
\hline
\end{tabular}




\begin{tabular}{|c|c|c|c|c|}
\hline & & & & Окончание табл.1 \\
\hline Период & $\begin{array}{l}\text { Институ- } \\
\text { циональ- } \\
\text { ный блок }\end{array}$ & Документ (организация), год принятия (создания) & $\begin{array}{c}\text { Институт } \\
\text { регулиро- } \\
\text { вания } \\
\end{array}$ & $\begin{array}{c}\text { Основной объект регулирования в сфере } \\
\text { цифровизации }\end{array}$ \\
\hline \multirow{10}{*}{ 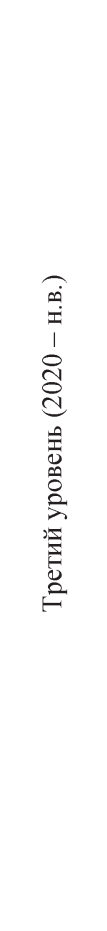 } & \multirow{4}{*}{ ИБЗК } & $\begin{array}{l}\text { Европейская организация кибербезопасности (ECSO), } \\
2016\end{array}$ & ЕК & $\begin{array}{c}\text { Оказание содействия в условиях } \\
\text { кибератак }\end{array}$ \\
\hline & & $\begin{array}{c}\text { Директива о безопасности сетевых и информационных } \\
\text { систем EC (NIS), } 2016\end{array}$ & ЕК, ЕП, СЕ & Защита критической инфраструктуры \\
\hline & & $\begin{array}{c}\text { Коммюнике «Прокладывая путь к эффективному } \\
\text { и подлинному Союзу безопасности», концепция Союза } \\
\text { безопасности EC (Security Union), } 2016\end{array}$ & EK & Комплексная киберзащита \\
\hline & & Общий регламент о защите данных (GDPR), 2018 & $\begin{array}{l}\text { EK, EП, } \\
\text { CE, EDPS }\end{array}$ & Персональные данные \\
\hline & СЦ & - & - & - \\
\hline & ИБЦИ & $\begin{array}{l}\text { Проект регуляторной политики в области } \\
\text { искусственного интеллекта (ИИ), } 2021 \\
\end{array}$ & EK & Искусственный интеллект \\
\hline & ИБФР & - & - & - \\
\hline & \multirow{3}{*}{ ИБЗК } & Стратегия Союза безопасности ЕС, 2020 & EK & $\begin{array}{l}\text { Устранение цифровых и физических } \\
\text { рисков комплексным образом во всей } \\
\text { экосистеме Союза безопасности }\end{array}$ \\
\hline & & $\begin{array}{c}\text { Директива о безопасности сетевых и информационных } \\
\text { систем EC (NIS2), } 2020\end{array}$ & ЕП, СЕ, & $\begin{array}{c}\text { Усиление защиты критической } \\
\text { инфраструктуры }\end{array}$ \\
\hline & & $\begin{array}{c}\text { Проект создания нового европейского центра } \\
\text { компетенций в области промышленной, } \\
\text { технологической и исследовательской } \\
\text { кибербезопасности и сети национальных } \\
\text { координационных центров }\end{array}$ & EK & Противодействие киберпреступлениям \\
\hline
\end{tabular}

Примечание. СЦ - стратегия цифровизации; ИБЦИ - институциональный блок механизмов внедрения и регулирования отдельных цифровых инноваций и концепций; ИБФР - институциональный блок регулирования финансового рынка; ИБЗК - институциональный блок защиты киберпространства.

ЕК - Европейская комиссия; СЕ - Совет Европы; ЕП - Европейский парламент; ЕІС - Расширенный Европейский инновационный совет; ЕIT - Европейский институт инноваций и технологий; BEREC - Opган европейских коммуникационных регуляторов; ESMA - Европейское управление по ценным бумагам и рынкам; EBA - Европейское банковское управление; EDPS -Европейский надзорный орган по защите данных.

Источник. Авторская разработка.

ной зоны (SEPA) - инициативы ЕС по интеграции европейской системы розничных электронных платежей. Блок киберзащиты характеризуется созданием нового специализированного института - Европейской организации кибербезопасности (ECSO), а также формированием нового концепта Союза безопасности ЕC (Security Union).

Третий (современный) уровень развития институциональной экосистемы - общая стратегия цифровизации - находится в стадии формирования. На уровне институционального блока цифровых технологий особое внимание уделяется искусственному интеллекту. Финансовый блок проходит дополнительные исследования и согласования с учетом новых вызовов для национальных финансовых систем со стороны цифровых валют. Вместе с тем очевидна определяющая роль киберзащиты в дальнейшей цифрови- зации различных отраслей и сегментов экономики, социальной сферы и государственных институтов. Разрабатывается проект создания нового европейского центра компетенций в области промышленной, технологической и исследовательской кибербезопасности и сети национальных координационных центров. В развитие концепта Союза безопасности ЕС принята его стратегия, которая направлена на создание коллективных возможностей для реагирования на крупные кибератаки. В нем также изложены планы работы с партнерами по всему миру для обеспечения международной безопасности и стабильности в киберпространстве, описывается, как совместное киберподразделение может обеспечить наиболее эффективный ответ на киберугрозы, используя коллективные ресурсы и опыт, доступные государствам-членам и ЕС. Подход ЕС к внешней безопаснос- 
ти в рамках Общей внешней политики и политики безопасности (CFSP) и Общей политики безопасности и обороны (CSDP) останется важным компонентом усилий ЕC по укреплению безопасности внутри ЕC.

\section{Институциональная матрица для Республики Беларусь}

Распространение мировых тенденций цифровизации затрагивает Республику Беларусь, ее экономическое развитие, конкурентоспособность как отдельных видов продукции, так и экономики в целом, проблематику обеспечения экономической безопасности, связанную с внедрением новых технологий в ключевые сферы жизнедеятельности государства.

Отличительной характеристикой институциональной среды цифровой экономики Республики Беларусь является наличие специального инновационного кластера, резиденты которого занимаются разработкой программных продуктов и предоставлением IT-услуг - Парка высоких технологий (ПВТ). Данный институт регуляторной среды создан в 2005 г. и представляет собой особую экономическую зону со специальным налогово-правовым режимом, способствующую благоприятному развитию IT-бизнеса. В рамках пред- ставленной модели ПВТ функционально является составным элементом как технологического, так и финансового блоков, поскольку посредством кластера государство стимулирует как технологические, так и FinTech направления развития (табл. 2).

Таким образом, сравнительный анализ формирования институциональной экосистемы для развития цифровой экономики в Республике Беларусь показал, что хоть и с опозданием, но наша страна адаптирует действующие механизмы управления к современным требованиям цифровизации. От централизованной формы государственного управления цифровой экономикой Республика Беларусь поступательно движется к смешанной, используя механизмы государственно-частного партнерства.

Важно отметить, что с учетом методологий оценки цифровизации экономики, предложенной рядом организаций ${ }^{9}$, ключевыми критериями развития государства являются: наличие устойчивой экономики, сильного кадрового резерва, высококачественной цифровой инфраструктуры и динамичной технологической экосистемы. Республика Беларусь имеет как сильные, так и слабые стороны.

${ }^{9}$ Digital Challengers in the next normal in Central and Eastern Europe. 2020. URL https://www.mckinsey.com/ business-functions/mckinsey-digital/our-insights/digitalchallengers-in-the-next-normal-in-central-and-eastern-europe

Таблица 2

Институциональная матрица экосистемы цифровой экономики Республики Беларусь

\begin{tabular}{|c|c|c|c|c|}
\hline Период & $\begin{array}{l}\text { Институ- } \\
\text { циональ- } \\
\text { ный блок }\end{array}$ & $\begin{array}{c}\text { Документ (организация), год принятия } \\
\text { (создания) }\end{array}$ & $\begin{array}{c}\text { Институт } \\
\text { регулирова- } \\
\text { ния } \\
\end{array}$ & $\begin{array}{c}\text { Основной объект регулирования в сфере } \\
\text { цифровизации }\end{array}$ \\
\hline \multirow{8}{*}{ 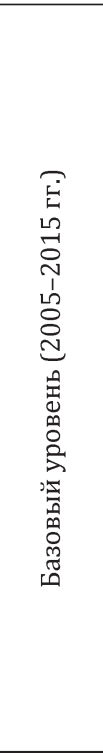 } & \multirow[b]{2}{*}{ СЦ } & $\begin{array}{c}\text { Стратегия развития информационного } \\
\text { общества на период до } 2015 \text { года, } \\
\text { утверждена Постановлением Совета } \\
\text { Министров Республики Беларусь } \\
\text { от } 9 \text { августа } 2010 \text { г. № } 1074\end{array}$ & \multirow[b]{2}{*}{ Прав } & \multirow{2}{*}{$\begin{array}{c}\text { Формирование базового комплекса } \\
\text { электронного правительства, включая } \\
\text { общегосударственную } \\
\text { автоматизированную информационную } \\
\text { систему, систему межведомственного } \\
\text { электронного документооборота, систему } \\
\text { управления открытыми ключами } \\
\text { проверки электронной цифровой подписи, } \\
\text { единое расчетное информационное } \\
\text { пространство }\end{array}$} \\
\hline & & $\begin{array}{c}\text { Национальная программа ускоренного } \\
\text { развития услуг в сфере информационно- } \\
\text { коммуникационных технологий на 2011- } \\
2015 \text { годы, отраслевые и региональные } \\
\text { программы информатизации }\end{array}$ & & \\
\hline & \multirow{3}{*}{ ИБЦИ } & $\begin{array}{c}\text { Декрет № } 12 \text { от } 22 \text { сентября } 2005 \text { г. «0 Парке } \\
\text { высоких технологий» }\end{array}$ & ПР & Сектор ИКТ \\
\hline & & $\begin{array}{c}\text { Закон Республики Беларусь от } 28 \text { декабря } \\
2009 \text { г. № } 113-3 \text { «Об электронном документе } \\
\text { и электронной цифровой подписи» }\end{array}$ & Пар, Прав & Электронный документооборот \\
\hline & & С000 «Белорусские облачные технологии» & $\begin{array}{c}\text { ОАЦ, } \\
\text { Минсвязи }\end{array}$ & Рынок облачных решений \\
\hline & ИБФР & - & - & - \\
\hline & \multirow{2}{*}{ ИБЗК } & $\begin{array}{c}\text { Закон Республики Беларусь от } 10 \text { ноября } \\
2008 \text { г. № 455-3 «Об информации, } \\
\text { информатизации и защите информации» }\end{array}$ & Пар & $\begin{array}{c}\text { Области информации, информатизации } \\
\text { и защиты информации }\end{array}$ \\
\hline & & $\begin{array}{c}\text { Оперативно-аналитический центр при } \\
\text { Президенте Республики Беларусь (Указ } \\
\text { Президента от } 1 \text { апреля } 2008 \text { г.) } \\
\end{array}$ & ПР & $\begin{array}{c}\text { Обеспечение защиты информации, содер- } \\
\text { жащей сведения, составляющие госу- } \\
\text { дарственные секреты Республики Беларусь }\end{array}$ \\
\hline
\end{tabular}


Окончание табл. 2

\begin{tabular}{|c|c|c|c|c|}
\hline Период & $\begin{array}{l}\text { Институ- } \\
\text { циональ- } \\
\text { ный блок }\end{array}$ & $\begin{array}{c}\text { Документ (организация), год принятия } \\
\text { (создания) }\end{array}$ & $\begin{array}{c}\text { Институт } \\
\text { регулирова- } \\
\text { ния } \\
\end{array}$ & $\begin{array}{c}\text { Основной объект регулирования } \\
\text { в сфере цифровизации }\end{array}$ \\
\hline \multirow{12}{*}{ 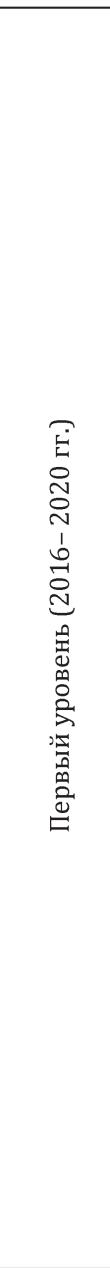 } & \multirow{2}{*}{ СЦ } & $\begin{array}{c}\text { Стратегия развития информатизации } \\
\text { в Республике Беларусь на 2016-2022 годы, } \\
\text { утверждена Постановлением Совета } \\
\text { Министров от 03.11.2015 г. № } 26\end{array}$ & \multirow{2}{*}{ Прав } & \multirow{2}{*}{$\begin{array}{c}\text { Внедрение передовых ИКТ во все сферы } \\
\text { человеческой жизнедеятельности; } \\
\text { создание, модернизация и внедрение } \\
\text { специализированных } \\
\text { автоматизированных информационных } \\
\text { систем (АИС); } \\
\text { развитие Интернет-платформ } \\
\text { (краудфандинга) }\end{array}$} \\
\hline & & $\begin{array}{c}\text { Государственная программа развития } \\
\text { цифровой экономики и информационного } \\
\text { общества на 2016-2020 годы }\end{array}$ & & \\
\hline & \multirow{5}{*}{ ИБЦИ } & $\begin{array}{c}\text { Совет по развитию цифровой экономики, } \\
\text { Постановление Совета Министров Республики } \\
\text { Беларусь от } 28 \text { февраля } 2018 \text { г. № } 167\end{array}$ & $\begin{array}{l}\text { Прав, } \\
\text { Минсвязи }\end{array}$ & $\begin{array}{c}\text { Координация деятельности по } \\
\text { реализации государственной политики } \\
\text { в сфере цифровой трансформации } \\
\text { экономики } \\
\end{array}$ \\
\hline & & $\begin{array}{c}\text { Перевод некоторых административных } \\
\text { процедур для юридических лиц и } \\
\text { индивидуальных предпринимателей в разряд } \\
\text { «цифровых» через единый портал } \\
\text { электронных услуг (Распоряжение Совета } \\
\text { Министров, апрель } 2020 \text { г.) }\end{array}$ & Прав & \multirow[t]{2}{*}{ Цифровое правительство } \\
\hline & & $\begin{array}{c}\text { Белорусская интегрированная сервисно- } \\
\text { расчетная система (БИРС) }\end{array}$ & \begin{tabular}{c|} 
Прав, \\
Минсвязи
\end{tabular} & \\
\hline & & $\begin{array}{c}\text { Технический комитет по стандартизации ТК ВУ } \\
38 \text { «Цифровая трансформация» }\end{array}$ & \begin{tabular}{c|} 
Прав, \\
Госстандарт
\end{tabular} & $\begin{array}{c}\text { Государственные стандарты в сфере } \\
\text { цифровой трансформации } \\
\text { промышленности }\end{array}$ \\
\hline & & \multirow[t]{2}{*}{$\begin{array}{l}\text { Декрет № } 8 \text { «0 развитии цифровой } \\
\text { экономики» (декабрь } 2017 \text { г.) }\end{array}$} & \multirow{2}{*}{ ПР } & \multirow{2}{*}{$\begin{array}{c}\text { Расширение разрешенных видов } \\
\text { деятельности для резидентов ПВТ, } \\
\text { блокчейн и криптовалюты, ICO и смарт- } \\
\text { контракты } \\
\end{array}$} \\
\hline & \multirow{3}{*}{ ИБФР } & & & \\
\hline & & $\begin{array}{c}\text { Инструкция об общих принципах } \\
\text { функционирования информационной сети, } \\
\text { построенной с использованием технологии } \\
\text { блокчейн (июль } 2017 \text { г.) } \\
\end{array}$ & Нацбанк & Блокчейн \\
\hline & & $\begin{array}{l}\text { Центр мониторинга и противодействия } \\
\text { компьютерным атакам в кредитно-- } \\
\text { финансовой сфере (создан в } 2018 \text { г.) }\end{array}$ & Нацбанк & $\begin{array}{c}\text { Кибератаки и мошенничество } \\
\text { с использованием электронных } \\
\text { платежных инструментов и средств } \\
\text { платежа } \\
\end{array}$ \\
\hline & \multirow[t]{2}{*}{ иБЗК } & $\begin{array}{c}\text { Концепция информационной безопасности } \\
\text { Республики Беларусь, утверждена } \\
\text { Постановлением Совета Безопасности } \\
\text { Республики Беларусь от } 18 \text { марта } 2019 \text { г. № } 1\end{array}$ & ПР, СБ & $\begin{array}{l}\text { Цифровые угрозы в промышленности, } \\
\text { на транспорте, в энергетике, } \\
\text { электросвязи, здравоохранении } \\
\text { и системах жизнеобеспечения }\end{array}$ \\
\hline & & $\begin{array}{c}\text { Концепция обеспечения кибербезопасности } \\
\text { в банковской сфере }\end{array}$ & Нацбанк & Киберриски в банковской деятельности \\
\hline \multirow{7}{*}{ 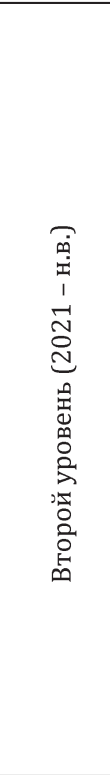 } & Сц & $\begin{array}{l}\text { Государственная программа «Цифровое } \\
\text { развитие Беларуси» на 2021-2025 годы }\end{array}$ & Прав & $\begin{array}{c}\text { Реализация концептов «Умный город», } \\
\text { «Промышленность 4.0», создание не } \\
\text { менее } 7 \text { государственных цифровых } \\
\text { платформ } \\
\end{array}$ \\
\hline & \multirow[b]{2}{*}{ ИБЦИ } & $\begin{array}{c}\text { Указ Президента Республики Беларусь № } 107 \\
\text { от } 16 \text { марта 2021 г. «0 биометрических } \\
\text { документах» }\end{array}$ & ПР & \multirow[b]{2}{*}{ Цифровое правительство } \\
\hline & & $\begin{array}{c}\text { Агентство сервисизации и реинжиниринга, } \\
\text { постановление Совета Министров } \\
\text { Республики Беларусь № } 646 \text { от } 15 \text { ноября } 2021 \text { г. } \\
\text { «0 снижении административной нагрузки } \\
\text { и цифровизации административных } \\
\text { процедур» } \\
\end{array}$ & Прав & \\
\hline & ИБФР & $\begin{array}{c}\text { Указ № } 196 \text { «0 сервисах онлайн- } \\
\text { заимствования и лизинговой деятельности» }\end{array}$ & $\begin{array}{c}\text { ПР, } \\
\text { Нацбанк }\end{array}$ & Сервисы онлайн -заимствования \\
\hline & \multirow[t]{3}{*}{ иБЗК } & $\begin{array}{c}\text { Подпрограммы «Информационная } \\
\text { безопасность» и «Цифровое доверие» в рамках } \\
\text { Государственной программы «Цифровое } \\
\text { развитие Беларуси» на 2021-2025 годы» }\end{array}$ & ОАЦ & $\begin{array}{c}\text { Программные и программно- } \\
\text { аппаратные средства защиты } \\
\text { информационных ресурсов, } \\
\text { информационных } \\
\text { и телекоммуникационных систем }\end{array}$ \\
\hline & & $\begin{array}{c}\text { Закон от 07.05.2021 № 99-3 «0 защите } \\
\text { персональных данных» }\end{array}$ & Пар, ОАЦ & \multirow[b]{2}{*}{ Цифровые персональные данные } \\
\hline & & $\begin{array}{c}\text { Национальный центр защиты персональных } \\
\text { данных, в соответствии с Указом № } 422 \text { от } 28 \\
\text { октября 2021 г. «О мерах по совершенствованию } \\
\text { защиты персональных данных» }\end{array}$ & ПР, ОАЦ & \\
\hline
\end{tabular}

Примечание. ПР - Президент Республики Беларусь, Прав - Правительство Республики Беларусь, Пар - Парламент Республики Беларусь, СБ - Совет Безопасности Республики Беларусь, ОАЦ - Объединенный аналитический центр; Минсвязи - Министерство связи и коммуникаций Республики Беларусь; Нацбанк - Национальный банк Республики Беларусь; Госстандарт - Государственный комитет по стандартизации Республики Беларусь.

Источник. Авторская разработка. 
1. Макроэкономическая ситуация в Беларуси в 2021 г. усложняется. Санкционные и антисанкционные мероприятия в отношении страны, политическая и правовая неопределенность препятствуют обеспечению стабильного экономического роста, повышению конкурентоспособности экономики.

2. Преимуществом страны является квалифицированная рабочая сила, стоимость которой остается конкурентоспособной по сравнению с более развитыми в экономическом плане государствами.

3. Требуется дальнейшее внедрение цифровых технологий в систему среднего образования и увеличение подготовки IT-кадров в системе высшего образования.

4. Развитая цифровая инфраструктура в стране, льготный режим функционирования ПВТ сохраняют при прочих равных привлекательный характер для осуществления определенных IT-операций в Беларуси (услуги аутсорсинга, тестирования и пр.). При этом продуктовая направленность IT-компаний ввиду складывающейся внутренней и внешней конъюнктуры будет сокращаться.

5. Ключевым фактором в данной связи является резкое снижение инвестиционной привлекательности страны. Внутренние инвестиционные (венчурные) ресурсы носят чрезвычайно ограниченный характер и представлены главным образом на уровне таких организаций и компаний, как: Белинфонд ${ }^{10}$, инвестиционная компания Bulba Ventures ${ }^{11}$, инвестиционная организация Haxus ${ }^{12}$. В этой связи дополнительное сокращение возможностей для привлечения внешнего финансирования на внутреннем рынке будет способствовать регистрации управляющих компаний (офисов) за пределами Республики Беларусь, что приведет к поступательному исходу перспективных IT-проектов из страны.

${ }^{10}$ Создан в 1998 г. и является некоммерческой организацией, находящейся в подчинении Государственного комитета по науке и технологиям Республики Беларусь. Средства для финансирования проектов выделяются Белинфонду из бюджета. Объекты финансирования - преимущественно инновационные проекты крупных организаций, а не стартапы.

${ }^{11}$ Создана в марте 2018 г. Основная концепция: вкладывать усилия и время в ограниченное количество проектов.

${ }_{12}$ Компания зарегистрирована на Кипре, но большая часть команды - белорусы. Проинвестировано три сверхуспешных проекта: AIMATTER; MSQRD; maps.me.
От оперативности и результативности решения данных проблем во многом будет зависеть формирование устойчивой макроэкономической среды, необходимой для эффективного формирования цифровой экосистемы в Республике Беларусь.

Как показал приведенный анализ, по уровню комплексности и системности принимаемых управленческих решений по построению действенной экосистемы цифровой экономики Республика Беларусь значительно отстает от образцовых международных практик. Наша страна осуществляет стратегическое планирование развития данной сферы посредством разработки и реализации цифровых программ. Вместе с тем финансовые ограничения не позволяют проводить широкомасштабное внедрение цифровых технологий на государственном уровне наравне со странами-соседями. Институциональный технологический и финансовые блоки являются плохо проработанными и имеют скорее рамочную, неразработанную форму в отношении современных цифровых инноваций (таких, например, как искусственный интеллект, облачные вычисления, блокчейн, FinTech и пр.). Институциональный блок, связанный с киберзащитой, нуждается в серьезной трансформации с учетом нарастающего объема цифровых угроз и низкой подготовленности национальной инфраструктуры к такого рода вызовам ${ }^{13}$. Системное решение по формированию экосистемы, отвечающей требованиям современной цифровой экономики, позволят Республике Беларусь повысить эффективность и нарастить потенциал инфраструктурной и кадровой составляющих цифровизации, создать условия для комплексного внедрения новых цифровых технологий в различных сферах производства, государственного управления и социальной сферы страны, повысить конкурентоспособность национальной экономики.

${ }_{13}$ Республика Беларусь в Глобальном индексе кибербезопасности Международного союза электросвязи (ITU) получила достаточно низкий рейтинг (89 место из 194 стран). Низкие ее оценки по таким показателям, как: обучение в сфере кибербезопасности, разработка национальных стратегий в сфере кибербезопасности, технические возможности национальных и отраслевых регуляторов. Средние оценки выставлены по таким показателям, как: нормативное регулирование в отношении кибербезопасности и противодействия киберпреступности, сотрудничество агентств, компаний и государств. URL https://www.itu.int/dms_pub/itu-d/opb/str/D-STRGCI.01-2021-PDF-E.pdf 


\section{СПИСОК ЛИТЕРАТУРЫ (REFERENCES)}

Быков А.А., Шаблинская Т.В. 2020. Декомпозиция факторов экономического роста, основанного на спросе, с применением методологии межотраслевого баланса. Белорусский экономический журнал. № 1. С. 4-21. [Bykau A,, Shablinskaya T. 2020. Decomposition of demand-driven economic growth factors using input-output methodology. Belorusskiy ekonomicheskiy zhurnal. No 1. PP. 4-21. (In Russ.)]

Миллер Я.В. 2020. Создание добавленной стоимости в контексте сложности измерения цифровой экономики. E-Management. Т. 3. № 1. С. 6874. [Miller Y.V. 2020. Creation of added value in the context of measurement complexity of the digital economy. E-Management. Vol. 3. No 1. PP. 68-74. (In Russ.)]

Новикова И.В. 2020. От инновационного кластера к кросс-кластерному взаимодействию в интеграционных группировках: необходимые элементы и институты. Трудь БГТУ. Серия 5: Экономика и управление. № 2. C. 5-12. [Novikova I.V. 2020. From an innovative cluster to cross-cluster interaction in integration groups: elements and institutions necessary. Trudy BGTU. Seriya 5: Ekonomika i upravlenie. No 2. PP. 5-12. (In Russ.)]

Новикова И.В. 2020. Цифровая техноэкономическая парадигма в смене стратегии цифровизации Республики Беларусь. Труды БГТУ. Серия 5: Экономика и управление. № 1. С. 5-12. [Novikova I.V. 2020. Digital techno-economic paradigm in changing the digitalization strategy of the Republic of Belarus. Trudy BGTU. Seriya 5: Ekonomika i upravlenie. No 1. PP. 5-12. (In Russ.)]

Норт Д. 1997. Институты, институциональные изменения и функционирование экономики. Москва: Фонд экономической книги «НАЧАЛА». [North D. 1997. Institutions, institutional change and economic performance. Moscow: Fond ekonomicheskoy knigi «NAChALA». (In Russ.)]

Полтерович В.М. 2017. Институты догоняющего развития и гражданская культура. Научнье труды Вольного экономического общества Россuи. T. 205. № 3. C. 314-328. [Polterovich V.M. 2017. Institutions of catching-up development and civil culture. Nauchnye trudy Vol'nogo ekonomicheskogo obshchestva Rossii. Vol. 205. No 3. PP. 314-328. (In Russ.)]

Хантингтон С. 2004. Политический порядок в меняющихся обществах. Москва: ПрогрессТрадиция. [Huntington S. 2004. Political order in Changing Societies New Haven. Moscow: ProgressTpaditsiya. (In Russ.)]

Ходжсон Д. 2003. Экономическая теория и институты: манифест современной институциональной экономической теории. Москва: Дело. 465 c. [Hodgson G. 2003. Economics and Institutions:
A Manifesto for a Modern Institutional Economics. Moscow: Delo. 465 p. (In Russ.)]

Acemoglu D., Johnson S., Robinson J.A. 2005. Institutions as the Fundamental Cause of Long-run Growth. NBER. Working Paper No 10481. URL: https://www.nber.org/system/files/working_papers/ w10481/w10481.pdf

Ayres P. 2012. Shaping ecology: the life of Arthur Tansley. Wiley InterScience (Online service). Chichester, West Sussex, UK: Wiley-Blackwell.

Dahlman C.J. 1979. The Problem of Externality. Journal of Law and Economics. Vol. 22. No 1. PP. 141-162.

Ding J. 2018. Deciphering China's AI dream: the context, components, capabilities, and consequences of China's strategy to lead the world in AI. Centre for the Governance of AI, Future of Humanity Institute, University of Oxford. PP. 1-44.

Frankel M. 1962. The production function in allocation and growth: a synthesis. The American Economic Review. Vol. 52. No 5. PP. 995-1022.

Freeman C., Soete L. 1997. The Economics of Industrial Innovation. London, Pinter Publ. P. 306.

Giannopoulos G., Munro J. 2019. Innovation Organization and Governance Around the World. The Accelerating Transport Innovation Revolution. Elsevier. PP. 53-81.

Overby H., Audestad J. 2018. Digital Economics: How Information and Communication Technology is Shaping Markets, Businesses, and Innovation. CreateSpace Independent Publishing Platform. 262 p.

Peters M., Schneider M., Griesshaber T., Hoffmann V. 2012. The impact of technology-push and demand-pull policies on technical change - Does the locus of policies matter? Research Policy. Vol. 41. PP. 1296-1308.

Schuelke-Leech B.-A. 2017. A model for understanding the orders of magnitude of disruptive Technologies. Technological Forecasting \& Social Change. Vol. 129. PP. 261-274.

Searle J. 1995. The Construction of Social Reality. New York: Free Press.

Stefanoski D., Sahin O. Are platforms trading crypto-assets subject to MiFID II/MiFIR? 22 January 2019. Available at URL: https:// www.newrealityblog.com/2019/01/22/are-platformstrading-crypto-assets-subject-to-mifid-ii-mifir/

Streeck W., Thelen K. (Eds.). 2005. Beyond Continuity: Institutional Change in Advanced Political Economies. Oxford Press. 312 p.

Tilson D., Lyytinen K., Sorensen C. 2010. Research commentary-digital infrastructures: the missing IS research agenda. Information Systems Research. 21(4). PP. 748-759.

Williamson O.E. 1985. The Economic Institutions of Capitalism: Firms, Markets, Relational Contracting. P. 1. London: Macmillan. 
In citation: Belorusskiy Ekonomicheskiy zhurnal. 2021. No 4. PP. 124-137.

Belarusian Economic Journal. 2021. No 4. PP. 124-137.

\title{
FORMATION OF THE ECOSYSTEM OF THE DIGITAL ECONOMY: TECHNOLOGICAL AND INSTITUTIONAL ASPECTS, INTERNATIONAL EXPERIENCE AND IMPLEMENTATION IN THE REPUBLIC OF BELARUS
}

\author{
Irina Novikova ${ }^{1}$, Vitaly Krishtanosov ${ }^{1}$ \\ Author affiliation: ${ }^{1}$ Belarusian State Technological University (Minsk, Belarus). \\ Corresponding author: Vitaly Krishtanosov (krishtanosov@mail.ru).
}

ABSTRACT. The article studies problems in the creation of an ecosystem for the formation and development of the digital economy within an institutional context of development. It is shown that digitalization, by its nature, is an endogenous, technological factor of economic development and, therefore, it is becoming an important institution in modern conditions. The institutionalization of the digital economy is a methodologically complex process and requires taking into account the time factor and the sequence of actions of the public and private sectors in order to impart a consistent character and dynamics to economic processes. This approach is analysed on the basis of the emerging practice of forming the institutions of the digital economy in the Republic of Belarus, and the study of the key criteria necessary for its formation and development.

KEYWORDS: digital economy, institutional matrix of the digital economy ecosystem, three levels of the development of the digital economy ecosystem.

JEL-code: O33, O38, F52.

DOI: $10.46782 / 1818-4510-2021-4-124-137$

Received $\quad 6.12 .2021$ 